the International Congress of Hygiene in London in August mext. I believe the programme is already printed, but that ought not to preclude a subject which is exceedingly cipropos to the scope and objects of the Congress.

I am, Sirs, yours truly,

Town Hall, Halifax, May 15th, 1891.

D. Ainley.

* * We commend the suggestion of our correspondent to the notice of the authorities of the Congress.-ED. $\mathrm{L}$.

\section{LIABILITY OF LEAD-MINERS TO LEAD-POISONING.}

To the Editors of THE LANCET.

Sirs,--Your issue of March 7th is just to hand with a report of Dr. Oliver's first lecture (Gulstonian) on Leadpoisoning. I write to take exception to one remark in it wherein he very definitely states that " those engaged in lead mining never suffer." Here, in Broken Hill, we have very extensive lead mines, and our miners are very susceptible indeed to lead-poisoning, and of ten in a very severe form, more generally colic, but not infrequently coma and epileptiform convulsions. Further on Dr. Oliver remarks that "it is not the producer of the raw material who suffers; it is the smelter." We have also several smelters in blast here but although we sometimes get smelters suffering from lead poisoning, much more frequently we find it is the mine working down below, especially when working in the carBonate ore. I am, Sirs, yours truly,

J. BARTLEY, M.B., B.Ch.

Resident Surgeon, Broken Hill Hospital,

\section{LIVERPOOL.}

\section{(From oUR OWN CoRREspondent.)}

\section{The Royal Infirmary.}

THERE will be an election for an assistant surgeon to the Royal Infirmary on June 2nd. Mr, R. A. Bickersteth, Mr. George G. Hamilton, Mr. Damer Harrisson, Mr. Arthur MacLeod Ross, and Mr. Thelwall Thomas are candidates for the vacancy. The contest will be a very keen one, and the election will, unfortunately for all concerned, be as heretofore in the hands of the trustees-i.e., subscribers of two guineas and upwards, donors of twenty guineas and upwards, and the clergy and ministers who preached on Hospital Sunday, Jan. 11th last. This mode of election entails considerable expense and trouble to each candidate, as well as much annoyance to the trustees. It is confidently expected that this will be the last election by the trustees, and that all future vacancies will be filled by the decision of an elective committee.

Suspected Murder and Mutilation.

The body of a boy aged ten was found in a black sailor's bag floating in the Sandon Basin at 4 A.M. on the 19th inst. The legs had been cut and sawn off below the knees, in order that they might be got more easily into the bag; a new knife and saw were also in the bag. The body was examined externally by Mr. Paul, Lecturer on Forensic Medicine at the Liverpool University College, and a postmortem examination will be made to-day.

Death from Chloroform at the Royal Infirmary.

An inquest was held last week by the city coroner upon the body of a fruit porter aged thirty-six, who had been suffering from varicose veins. He was admitted into the Royal Infirmary, and consented to an operation being performed under chloroform. After being carefully examined, chloroform was administered by two trained assistants in the presence of one of the house surgeons. Before the deceased was properly under the influence of chloroform it was seen that something was wrong, his face becoming suddenly pale. The administration was at once stopped, and artificial respiration was immediately resorted to, but without arail. The deceased was apparently a healthy man, but at the post-mortem examination the heart was found to be in a state of fatty degeneration; this could not have been detected during life. So far as could be ascertained, the heart's action and respiration ceased simultaneously.

May 20 th.

\section{MANCHESTER.}

\section{(From oUR OWN CORRESPONDENT.)}

\section{The Infirmary and the College.}

THE second stage in the dispute between the Royal In. firmary and the College has now been reached. The Infirmary Board has issued to the public its reasons for refusing the site for a new hospital offered by the College. Summed up, they amount to this: that to extend the present institution by erecting a new building in Oxford-road would be more costly both in the first outlay and in the after main. tenance; that they have already three large separate branches to administer ; that a dual control with the College would inevitably lead to friction; that the present central position is more healthy and more convenient for patients as well as students : and that the building of a branch might ultimately lead to the removal of the entire institution from its present site. This manifesto is supported by a supplemental one from the Medical Board, who emphasise the advantages of the present site over the proposed new one. In reply, the College authorities immediately issued a counter-statement, putting before the public the case from their point of view. They insist that their primary object was the public good, and, secondly, the advancement and welfare of the medical school, which is an integral part of the College, and the interests of which they are bound to maintain and advance; that they have no wish or thought of removing or interfering with the present central infirmary; and that the public are quite competent to judge as to the expediency of further enlarging the old building or erecting a new one away from the crowded centre of the city. They assert that it is an anomaly that the College, which is practically the medical school, should have no control over an important part of their students' educationi.e., the clinical work, - and are sanguine that a scheme for conjoint representation on the governing body of the new hospital can be formulated, which would work satisfactorily and without friction; also that they will use their influence to obtain funds for building, and not leave this to the infirmary alone. Since these two sides of the question have been published, several free lances representing the opposing bodies have rushed into print, Dr. Ross and Messrs. Wright and Hardie representing the infirmary staff; whilst Drs. Sinclair and Leech have taken up the cudgels on behalf of Owens College. Apparently the next step must be an appeal to the public (as represented in the whole body of subscribers to the infirmary) as to whether the present building shall cr shall not be enlarged ; if not, then probably it will be left to the College to make the next move in getting a new hospital erected. The whole business has been an unfortunate one; but so far the weakness of the infirmary case is that the members of its staff are not unanimous in their verdict, at least one of the strongest supporters of the College being its senior physician, Dr. Leech.

\section{Influenza.}

The epidemic of influenza now prevailing here is quite as widespread as last year, and in many instances the attacks appear to be of greater sevexity. Amongst the numerous deaths which have been caused by it is that of the High Sheriff for Lancashire. Thirty-eight deaths were registered last week as primarily due to it, whilst no less than 146 were from respiratory diseases, nearly 100 per cent. in excess of the average. The death-rate last week was $42 \cdot 2$ per 1000 .

\section{Illness of Dr. Ward.}

Professor Ward, principal of Owens College, is in a critical condition from a severe attack of pneumonia, but it does not appear that this was connected with influenza. He has been attended by Drs. Leech and Dreschfeld, in addition to his own medical attendant. At the time of writing, some improvement in his condition is reported.

\section{Whitsuntide and the Weather.}

After a few days of summer temperature we have got back again into almost midwinter weather. On Saturday and Sunday heavy falls of rain, hail, and snow, accompanied by a biting north wind, theatened to utterly spoil the great carnival week of Lancashire and Yorkshire. From Sunday-school scholars to cotton princes, "Whit week" is for all and everyone a holiday time. Yesterday the sun did, however, temper the keen wind for the 20,000 children who went in annual procession through the streets 